\title{
9,10-ANTHRAQUINONE DERIVATIVES AS NEW PROMISING ANTIMICROBIAL COMPOUNDS
}

\section{Stasevych M. V., Zvarych V. I.}

\section{INTRODUCTION}

The 9,10-anthraquinone $\quad(9,10$-anthracenedione, $\quad 9,10$ dioxoanthracene) tricarbocyclic system over the past 150 years has been one of the key quinone molecular platforms, which has a powerful synthetic, applied and pharmacological potential, which is due to the peculiarities of reactivity and molecular affinity. Anthraquinonecontaining plants, such as buckthorn, alder buckthorn and rhubarb, have been known for their use in folk medicine for over 4,000 years. About 700 anthraquinone derivatives are found in plants, lichens and fungi; 43 already isolated and described from mushroom cultures ${ }^{1}$.

Synthetic derivatives of 9,10-anthraquinone have also enriched the arsenal of potential substances for drug development. The flat spatial structure of the aromatic anthracenedione nucleus provides its ability to DNA intercalation, which served as the basis for the discovery and implementation in clinical practice of such anticancer drugs as doxorubicin, aclarubicin, amixantrone and mitoxantrone. Their effectiveness prompted the development and search for new synthetic pharmacophore modifications of the anthraquinone ring, which led to the identification of a wide range of derivatives with significant antiproliferative activity $^{2}$. Gradually, derivatives of 9,10dioxoanthracene enriched the arsenal of biologically active substances, among which compounds with antiprotozoal, antiviral, antimicrobial,

${ }^{1}$ Fouillaud M., Venkatachalam M., Girard-Valenciennes E., Caro Y., Dufossé L. Anthraquinones and derivatives from marine-derived fungi: Structural Diversity and Selected Biological Activities. Marine Drugs. 2016. Vol. 14. № 4. 64.

${ }^{2}$ Tikhomirov A.S., Shtil A.A., Shchekotikhin A.E. Advances in the discovery of anthraquinone-based anticancer agents. Recent Patents on Anti-Cancer Drug Discovery. 2018. Vol. 13. P. 159-183.

Winkelmann E., Raether W. Chemotherapeutically active anthraquinones. I. Aminoanthraquinones. Arzneimittelforschung. 1979. Vol. 29. P. 1504-1509.

Malik E.M., Muller C.E. Anthraquinones as pharmacological tools and drugs. Medicinal Research Reviews. 2016. Vol. 3. P. 705-748. 
anti-inflammatory effects were identified ${ }^{3}$. However, in the aspect of research on biological activity, much attention is focused on the search for new anticancer substances, while other types of biological action are presented only by examples of individual representatives.

The study of antibacterial activity is mainly presented both for individual compounds and for extracts from natural anthraquinonecontaining plant sources, for which an inhibitory effect on strains of gram-negative bacteria Pseudomonas aeruginosa, Helicobacter pylori, Neisseria gonorrhoeae and gram-positive bacteria Staphylococcus aureus, particularly MRSA strains, and Staphylococcus epidermitis ${ }^{4}$. The results of the study of antifungal action are in the overwhelming majority presented for natural hydroxy-containing derivatives of 9,10 -anthraquinone and are summarized in the review ${ }^{5}$.

Considering the powerful biological potential of 9,10-anthraquinone derivatives in general and the limited amount of literature on the search and identification of compounds with antibacterial and antifungal properties among synthetic derivatives of 9,10-anthraquinone, the development of research in this direction is promising and relevant. The authors below present the generalized results of their many years of work during 2013-2021 to identify effective antimicrobial compounds among the number of derivatives of 9,10-anthraquinone synthesized by them.

3 Горелик М.В. Химия антрахинонов и их производных. Москва : Химия, 1983. 295 c.

Thomson Reuters Integrity database. URL: http:// https://integrity.clarivate.com/ integrity/xmlxsl/ (accessed December 14, 2019).

Ворожцов Н.Н. Основы синтеза промежуточных продуктов и красителей. Москва : ГосТехХимИздат, 1955. 840 с.

Эфрос Л.С., Горелик М.В. Химия и технология промежуточных продуктов. Ленинград : Химия, 1979. 544 с.

Sharma R.K., Salunkhe M. M. Solid-liquid phase transfer catalytic reaction of 1aminoanthraquinone with alkyl halides: A case of $\mathrm{N}$-alkylation. Indian journal of chemistry. Section B: Organic including medicinal chemistry. 1999. Vol. 38. P. 210-211.

Krasnokutskaya E.A., Semenischeva N.I., Filimonov V.D., Knochel P. A new, one-step, effective protocol for the iodination of aromatic and heterocyclic compounds via aprotic diazotization of amines. Synthesis. 2007. Vol. 1. P. 81-84.

Malmir M., Serrano R., Silva O.M. D. Anthraquinones as potential antimicrobial agents-A review. Antimicrobial research: Novel bioknowledge and educational programs 1st Edition / edited by A.M. Vilas. Spain : Formatex Research Center S.L.; 2017. 694 p.

${ }^{5}$ Masi M., Evidente A. Fungal bioactive anthraquinones and analogues. Toxins. 2020. Vol. 12. № 11. 714. 


\section{Antibacterial and antifungal action of linear 9,10-anthraquinone derivatives}

Structurally modified derivatives of 9,10-anthraquinone were chosen as objects for testing antimicrobial activity and identifying promising compounds (Fig. 1) . $^{6}$

Testing of antibacterial and antifungal activities for compounds of types 1-7 was carried out against strains of Escherichia coli B-906, Staphylococcus aureus 209-P, Mycobacterium luteum B-917, Candida tenuis VKM Y-70 and Aspergillus niger VKM F-1119 by the diffusion methods (determining the diameter of microorganism growth inhibition zones $\mathrm{d}, \mathrm{mm}$ at the test concentrations of $0.1 \%$ and $0.5 \%$ ) and the serial dilutions in the range of $0.9-500 \mu \mathrm{g} / \mathrm{ml}$ (determination the minimum inhibitory concentration MIC $\mu \mathrm{g} / \mathrm{ml})^{7}$. For a comparative assessment of

6 Zvarych V.I., Stasevych M.V., Lunin V.V., Novikov V.P., Vovk M.V. $\mathrm{N}$-Acylation of amino-9,10-anthraquinones by system of strong carboxylic acid ammonium thiocyanate. Журнал органічної та фармацевтичної хімії. 2015. Vol. 13. C. 35-40.

Zvarich V.I., Stasevich M.V., Stan'ko O.V., Komarovskaya-Porokhnyavets E.Z., Poroikov V.V., Rudik A.V., Lagunin A.A., Vovk M.V., Novikov V.P. Computerized prediction, synthesis, and antimicrobial activity of new amino-acid derivatives of 2chloro- $N$-(9,10-dioxo-9,10-dihydroanthracen-1-yl)acetamide. Pharmaceutical Chemistry Journal. 2014. Vol. 48. P. 584-588.

Zvarych V., Stasevych M., Novikov V., Vovk M. Synthesis and study of antimicrobial activity of 2-dithiocarbamate- $N$-(9,10-dioxo-9,10dihydroanthracenyl)acetamides. Biointerface Research in Applied Chemistry. 2021. V. 11. № 1. P. 7725-7734.

Zvarych V., Stasevych M., Lunin V., Deniz N.G., Sayil C., Ozyurek M., Guclu K., Vovk M., Novikov V. Synthesis and investigation of antioxidant activity of the dithiocarbamates derivatives of 9,10-anthracenedione. Monatshefte für Chemie. 2016. Vol. 147. P. 2093-2101.

Stasevych M., Zvarych V., Lunin V., Kopak N., Komarovska-Porokhnyavets O., Deniz N. G., Sayil C., Ozyurek M., Guclu K., Vovk M., Novikov V. Synthesis, investigation of antimicrobial and antioxidant activity of anthraquinonylhydrazones. Monatshefte für Chemie. 2018. Vol. 149. P. 1111-1119.

Zvarych V.I., Stasevych M.V., Lunin V.V., Vovk M.V., Novikov V. P. Synthesis of (1H-pyrrol-1-yl)anthracene-9,10-diones. Chemistry of Heterocyclic Compounds. 2016. Vol. 52. P. 421-423.

Zvarych V., Stasevych M., Novikov V., Rusanov E., Vovk M., Szweda P., Grecka K., Milewski S. Anthra[1,2-d][1,2,3]triazine-4,7,12(3H)-triones as a new class of antistaphylococcal agents: synthesis and biological evaluation. Molecules. 2019. Vol. 24. 4581.

7 Лабинская А.С. Микробиология с техникой микробиолоических исследований. Москва : Медицина, 1972. С. 91-93. 
the effect of the studied compounds, the antibacterial substance vancomycin (diameter of growth inhibition zones / MIC for E. coli $14.0 \mathrm{~mm} / 31.2 \mu \mathrm{g} / \mathrm{ml}$, S. aureus $15.0 \mathrm{~mm} / 3.9 \mu \mathrm{g} / \mathrm{ml}$, M. luteum $18.0 \mathrm{~mm} / 7.8 \mu \mathrm{g} / \mathrm{ml}$ ) and the antifungal agent nystatin (diameter of growth inhibition zones / MIC for C. tenuis $19.0 \mathrm{~mm} / 7.8 \mu \mathrm{g} / \mathrm{ml}$, A. niger $20.0 \mathrm{~mm} / 15.6 \mu \mathrm{g} / \mathrm{ml}$ ) were used as reference controls.

Among the $N$-acylamino derivatives 9,10-anthracenediones of type $\mathbf{1}$, no compounds with a pronounced antimicrobial effect were found by diffusion in the aforementioned strains of microorganisms. However, the fungus strain $C$. tenuis was found to be sensitive to the action of derivative $\mathbf{1 . 1}$ at $\mathrm{MIC}=15.6 \mu \mathrm{g} / \mathrm{ml}$ (Fig. 1), which was identified by the serial dilution method.<smiles>[R]C(=O)Nc1c([R])ccc2c1C(=O)c1ccccc1C2=O</smiles><smiles>[R]C(=O)NCC(=O)Nc1cccc2c1C(=O)c1ccccc1C2=O</smiles><smiles>[R]C(=S)SCC(=O)Nc1cccc2c1C(=O)c1ccccc1C2=O</smiles><smiles>[R1]c1cc([R1])c2c(c1SC(=S)N1CCCC1)C(=O)c1ccccc1C2=O</smiles><smiles>[R]c1cc2c(cc1SC(=S)N1CCCC1)C(=O)c1ccccc1C2=O</smiles><smiles>[R]C([R4])=NNc1c([R3])ccc2c1C(=O)c1ccccc1C2=O</smiles><smiles>[R]c1ccc2c(c1-n1cccc1)C(=O)c1ccccc1C2=O</smiles><smiles>[R]c1ccc(-n2nnc3c4c(ccc3c2=O)C(=O)c2ccccc2C4=O)cc1</smiles>

Fig. 1. Objects of experimental study of antimicrobial activity

The study of amino acid derivatives of 2-chloro- $N$-acetamide 2.1-2.6 for antibacterial and antifungal properties is presented in the work ${ }^{8}$. In

${ }^{8}$ Zvarich V.I., Stasevich M.V., Stan'ko O.V., Komarovskaya-Porokhnyavets E.Z., Poroikov V.V., Rudik A.V., Lagunin A.A., Vovk M.V., Novikov V.P. Computerized prediction, synthesis, and antimicrobial activity of new amino-acid derivatives of 2-chloro- $N$-(9,10-dioxo-9,10-dihydroanthracen-1-yl)acetamide. Pharmaceutical Chemistry Journal. 2014. Vol. 48. P. 584-588. 
particular, it was found by the diffusion method that the cultures of $E$. coli, fungi $C$. tenuis and $A$. niger are insensitive to the action of compounds 2.1-2.6 under the study. $S$. aureus turned out to be a sensitive bacterial strain when exposed to it at a concentration of $0.5 \%$ of such amino acid derivatives as 2.1-2.6 (Fig. 2), the activity of which prevailed or was at the level of vancomycin activity.

The growth of the $S$. aureus test culture via the study of exact MICs for the compounds in the concentration range of $0.9-500 \mu \mathrm{g} / \mathrm{ml}$ was observed. The culture strain of bacteria $M$. luteum by diffusion in agar experiments did not show high sensitivity to the tested derivatives. On the other hand, the activity for derivatives $\mathbf{2 . 4 - 2 . 6}$ by the method of serial dilutions was detected to $M$. luteum culture with the MIC $=7.8-250 \mu \mathrm{g} / \mathrm{ml}$. Antifungal properties against $C$. tenuis and A. niger strains at or above the effect of the reference drug nystatin were found for amino acid derivatives $\mathbf{2 . 4}$ and $\mathbf{2 . 6}$.

Considering that fungi of the Aspergillus genus are among the causative agents of nail onychomycosis ${ }^{9}$, including those caused by A. niger $^{10}$, an interesting direction was the study of the GABA derivative of 2-chloro- $N$-acetamide 2.6. Derivative $\mathbf{2 . 6}$ in the form of a varnish showed a high antifungal effect in comparison with the reference preparation nystatin relative to the $A$. niger test culture ${ }^{11}$. It should be noted that drugs in the form of varnish are optimal in the treatment of nail diseases, since they have a number of advantages ${ }^{12}$. As a basis for the preparation of an antifungal varnish with compound 2.6, we took a colorless nail polish "Nogotok" (Cosmetic-Service company, Ukraine) with the following components: ethyl acetate, butyl acetate, nitrocellulose, adipic acid/neopentyl glycol/trimellitic copolymer anhydride, acetyltributyl citrate, isopropyl alcohol. Terbinafine in the

9 Bongomin F., Batac C.R., Richardson M.D., Denning D.W. A review of onychomycosis due to Aspergillus species. Mycopathologia. 2018. Vol. 183. P. 485-493.

${ }^{10}$ Kim D.M., Suh M.K., Ha G.Y., Sohng S.H. Fingernail onychomycosis due to Aspergillus niger. Annals of dermatology. 2012. Vol. 24. P. 459-463.

11 Stasevych M., Zvarych V., Novikov V. Study of the antifungal action of the lacquer based on the GABA derivative of 2-chloro- $N$-(9,10-dioxo-9,10dihydroanthracen-1-yl)acetamide. Biointerface Research in Applied Chemistry. 2021. Vol. 11. № 2. P. 8818-8824.

${ }^{12}$ Yadav K. A review article on anti-fungal nail lacquer using treatment of onychomycosis. International Journal of Scientific and Research Publications. 2019. Vol. 9. № 4. P. 352-357. 
form of $1 \%$ nail varnish under the name Lamisil (manufactured by Delpharm Juning SAS, France) was taken as a reference drug. A varnish without the addition of antifungal agents was used as a control.

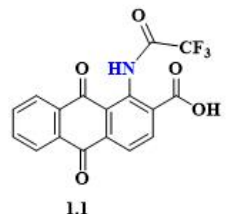

C. tenuis $\mathrm{d}=13.7 \mathrm{~mm}, \mathrm{MIC}=15.6 \mu \mathrm{g} / \mathrm{ml}$<smiles>CC(C)CC(NCC(=O)Nc1cccc2c1C(=O)c1ccccc1C2=O)C(=O)O</smiles>

S. aureus $\mathrm{d}=30 \mathrm{~mm}$ M. luteum $\mathrm{d}=8 \mathrm{~mm}$, $\mathrm{MIC}=15.6 \mu \mathrm{g} / \mathrm{ml}$

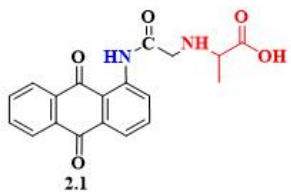

S. aureus $\mathrm{d}=16 \mathrm{~mm}$ M. luteum $\mathrm{d}=12 \mathrm{~mm}$

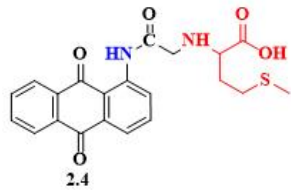

S. aureus $\mathrm{d}=20 \mathrm{~mm}$ M. luteum $\mathrm{d}=8 \mathrm{~mm}$, $\mathrm{MIC}=31.2 \mu \mathrm{g} / \mathrm{ml}$ A. niger $\mathrm{MIC}=15.6 \mu \mathrm{g} / \mathrm{ml}$

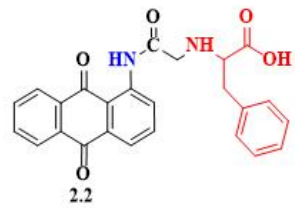

S. aureus $\mathrm{d}=18 \mathrm{~mm}$ M. luteum $\mathrm{MIC}=31.2 \mu \mathrm{g} / \mathrm{ml}$<smiles>O=C(O)CNCCC(=O)Nc1cccc2c1C(=O)c1ccccc1C2=O</smiles>

S. aureus $\mathrm{d}=16 \mathrm{~mm}$ M. luteum $\mathrm{d}=14.3 \mathrm{~mm}$, $\mathrm{MIC}=7.8 \mu \mathrm{g} / \mathrm{ml}$<smiles>CC(CNCC(=O)O)Nc1cccc2c1C(=O)c1ccccc1C2=O</smiles>

S. aureus $\mathrm{d}=15 \mathrm{~mm}$,

M. luteum $\mathrm{d}=11.3 \mathrm{MM}, \mathrm{MIC}=15.6 \mu \mathrm{g} / \mathrm{ml}$

A. niger $\mathrm{MIC}=1.9 \mu \mathrm{g} / \mathrm{ml}$

C. tenuis $\mathrm{MIC}=7.8 \mu \mathrm{g} / \mathrm{ml}$

Fig. 2. Active antimicrobial compounds among $N$-acylamino derivatives of 9,10-anthracenedione 1 and amino acid derivatives of 2 -chloro- $N$-acetamide 2

For the study, varnishes were prepared with a concentration of the derivative $\mathbf{2 . 6}$ of $1 \%, 0.5 \%$ and $0.1 \%$, respectively, and diluted varnish with terbinafine "Lamisil" to concentrations of $0.5 \%$ and $0.1 \%$. Then varnishes with appropriate concentrations, a control sample of varnish "Nogotok" and "Lamisil" were applied to glass slides, placed in Petri dishes and poured with agarized sterile medium under laminar conditions, a test culture was added, after which the dishes with the content were cultured at $28 \pm 1{ }^{\circ} \mathrm{C}$ in thermostat. The observation results were recorded after 24 hours (Fig. 3) and 72 hours (Fig. 4).

A fungicidal effect was recorded after incubation for $24 \mathrm{~h}$ (Fig. 3) in Petri dishes with derivative $\mathbf{2 . 6}$ at a concentration of $0.1 \%$, with the presence of an insignificant number of fungal colonies compared to the 
control, while terbinafine at the same concentration slightly prevailed. At a concentration of $0.5 \%$, compound $\mathbf{2 . 6}$ caused the same growth of the A. niger mycelium as in the control, while the amount of mycelium was higher under the action of terbinafine. At a concentration of $1 \%$, derivative 2.6 showed a fungicidal effect at the same concentration of terbinafine, while the control contained a lot of fungal mycelium ${ }^{13}$.

The results of observations after $72 \mathrm{~h}$ of incubation of the test culture showed that the control sample was completely overgrown with spores of the test culture of fungus A. niger. Compound $\mathbf{2 . 6}$ at a concentration of $0.1 \%$ exhibited only a fungistatic effect, instead of $0.1 \%$ terbinafine had a fungistatic and fungicidal effect. Derivative $\mathbf{2 . 6}$ and terbinafine had almost the same effect at a concentration of $0.5 \%$, as in the case of $0.1 \%$ concentration. Only in the case of $1 \%$ concentration for GABA-derivative $\mathbf{2 . 6}$, a zone of growth inhibition of A. niger was $22 \mathrm{~mm}$ in diameter, and a smaller number of fungal spores were outlined. While for a $1 \%$ concentration of the reference drug it was slightly less $(20 \mathrm{~mm})$, and a greater growth of spores was recorded for the test culture. Nevertheless, in both cases (derivative $\mathbf{2 . 6}$ and terbinafine) a $1 \%$ concentration caused fungicidal and fungistatic action. Thus, the results of the study of the derivative 2.6 in the form of a varnish, both after 24 hours and after 72 hours, indicate the prospects for further tests in this direction.

In vitro studies of the antimicrobial effect of dithiocarbamate 2chloro- $N$-acetamide derivatives type 3 showed that $E$. coli and $S$. aureus bacterial strains are insensitive in diffusion in agar experiments at $0.1 \%$ and $0.5 \%$ of studied concentrations ${ }^{14}$. Dithiocarbamates 3.1-3.3 showed their antibacterial effect against the bacterium $M$. luteum at a $0.5 \%$ concentration with the diameter of the growth inhibition zone $\mathrm{d}=19,20$ and $18 \mathrm{~mm}$, respectively (Fig. 5). Derivatives 3.1-3.4 proved to be the best in suppressing the growth of the test culture of fungus $C$. tenuis, for which the diameter of the zones at the same concentration was 17-26 $\mathrm{mm}$. For the same acyldithiocarbamates, the exact MICs were

${ }^{13}$ Stasevych M., Zvarych V., Novikov V. Study of the antifungal action of the lacquer based on the GABA derivative of 2-chloro- $N$-(9,10-dioxo-9,10dihydroanthracen-1-yl)acetamide. Biointerface Research in Applied Chemistry. 2021. Vol. 11. № 2. P. 8818-8824.

${ }^{14}$ Zvarych V., Stasevych M., Novikov V., Vovk M. Synthesis and study of antimicrobial activity of 2-dithiocarbamate- $N$-(9,10-dioxo-9,10dihydroanthracenyl)acetamides. Biointerface Research in Applied Chemistry. 2021. V. 11. № 1. P. 7725-7734. 
established by serial dilutions. It was found that compound $\mathbf{3 . 3}$ showed a MIC against the bacterial strain $M$. luteum at a concentration of $7.8 \mu \mathrm{g} / \mathrm{ml}$. Dithiocarbamate 3.4 caused the effect against $M$. luteum culture at a concentration two times lower $(\mathrm{MIC}=31.2 \mu \mathrm{g} / \mathrm{ml})$ than its isomeric analog 3.2 (MIC $=62.5 \mu \mathrm{g} / \mathrm{ml})$.

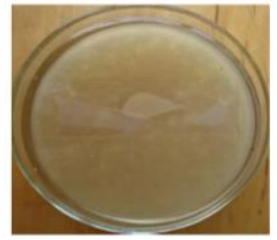

control

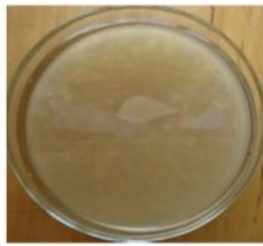

control

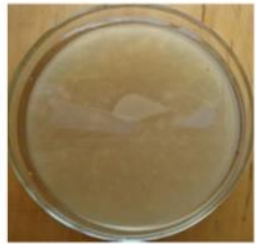

control

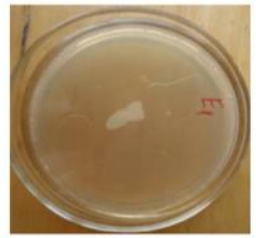

$0.1 \%$ of terbinafine

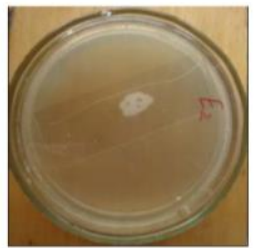

$0.5 \%$ of terbinafine

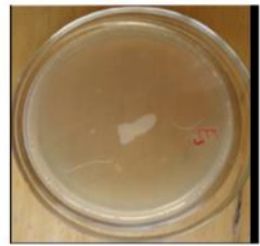

$1 \%$ of terbinafine

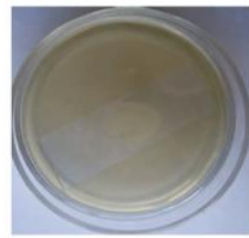

$0.1 \%$ of derivative 2.6

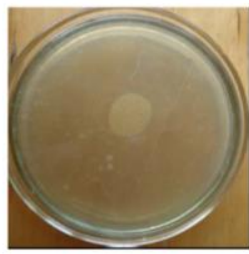

$0.5 \%$ of derivative 2.6

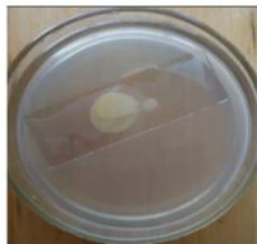

$1 \%$ of derivative 2.6

Fig. 3. An effect of derivative 2.6 and terbinafine at the corresponding concentrations of $0.1,0.5$ and $1 \%$ on the growth of fungus $A$. niger test culture of the in comparison with the control after $24 \mathrm{~h}$.

Among 9,10-dioxoanthracenyl dithiocarbamates of types $\mathbf{4}, \mathbf{5}^{15}$, pyrrolidine dithiocarbamates $\mathbf{4 . 1}$ and $\mathbf{5 . 3}$ were distinguished by a wide spectrum of antimicrobial activity against test cultures of E. coli, S. aureus, M. luteum, C. tenuis, and A. niger. In particular, compound 4.1 of all

${ }^{15}$ Zvarych V., Stasevych M., Lunin V., Deniz N.G., Sayil C., Ozyurek M., Guclu K., Vovk M., Novikov V. Synthesis and investigation of antioxidant activity of the dithiocarbamates derivatives of 9,10-anthracenedione. Monatshefte für Chemie. 2016. Vol. 147. P. 2093-2101. 
dithiocarbamates exhibited an effect on $E$. coli at $\mathrm{MIC}=3.9 \mu \mathrm{g} / \mathrm{ml}$, when the reference drug vancomycin was active at a concentration of $31.2 \mu \mathrm{g} / \mathrm{ml}^{16}$. Culture of $S$. aureus turned out to be sensitive to the action of dithiocarbamate derivatives $4.1,4.2,5.1,5.2$, and $M$. luteum strain was sentient of to the action of the compounds shown in Fig. 1.6. Derivatives 4.1, 4.2, 5.1, 5.2, 5.3 showed a high inhibitory effect on culture of fungus $C$. tenuis in the concentration range $0.9-62.5 \mu \mathrm{g} / \mathrm{ml}$, and dithiocarbamates 4.1, 5.2, 5.3 (Fig. 6) had the highest activity (MIC $=0.9 \mu \mathrm{g} / \mathrm{ml}, \mathrm{d}=19-21 \mathrm{~mm}$ ) compared with nystatin ( $\mathrm{MIC}=7.8 \mu \mathrm{g} / \mathrm{ml}$ ).

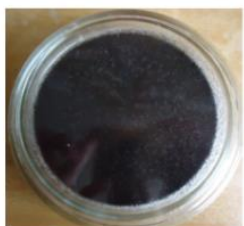

control

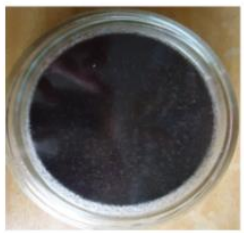

control

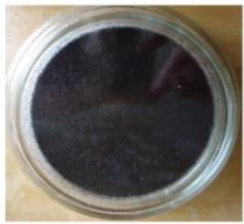

control

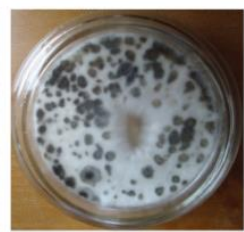

$0.1 \%$ of terbinafine

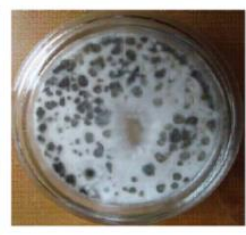

$0.5 \%$ of terbinafine

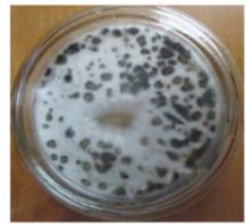

$1 \%$ of terbinafine

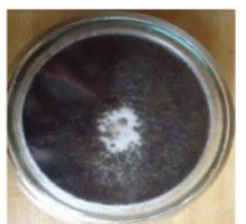

$\mathbf{0 . 1} \%$ of derivative $\mathbf{2 . 6}$

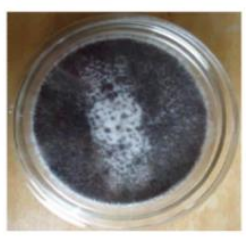

$\mathbf{0 . 5} \%$ of derivative $\mathbf{2 . 6}$

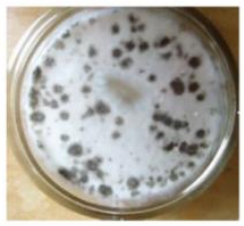

$1 \%$ of derivative $\mathbf{2 . 6}$

Fig. 4. An effect of derivative 2.6 and terbinafine at the corresponding concentrations of $0.1,0.5$ and $1 \%$ on the growth of fungus $A$. niger test culture of the in comparison with the control after $72 \mathrm{~h}$.

16 S-(9,10-Діоксо-9,10-дигідроантрацен-1-іл)піролідин-1-карбодитіоат, що має протипухлинну активність стосовно раку молочної залози людини та антимікробну дію: пат. 120193 Україна. № а201706996; заявл. 27.11.2017; опубл. 25.10.2019, Бюл. № 20. 6 с. 
Analysis of the data of antimicrobial testing of 9,10-dioxoanthracenyl dithiocarbamates 4, 5 made it possible to reveal some relationships between the structure and manifestation of activity towards a certain strain of the microorganism. The introduction of diethyldithiocarbamate residue into the molecule of 9,10-anthracenedione reduces both antibacterial and antifungal effects. Displacement of the pyrrolidinedithiocarbamate substituent in the position 2 leads to a disappearance of the antibacterial effect to E. coli, and when supplementing this residue with a chlorine atom in the position 3 of anthracene-9,10-dione additionally causes the disappearance of the effect on S. aureus culture.

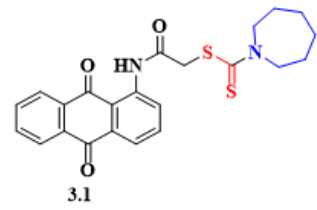

M. luteum $\mathrm{d}=19 \mathrm{~mm}$, $\mathrm{MIC}=250 \mu \mathrm{g} / \mathrm{ml}$ C. tenuis $\mathrm{d}=17 \mathrm{~mm}$, $\mathrm{MIC}=62.5 \mu \mathrm{g} / \mathrm{ml}$ A. niger $\mathrm{MIC}=125 \mu \mathrm{g} / \mathrm{ml}$

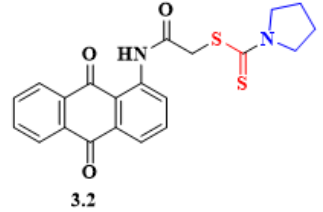

M. luteum $\mathrm{d}=20 \mathrm{~mm}$, $\mathrm{MIC}=62.5 \mu \mathrm{g} / \mathrm{ml}$ C. tenuis $\mathrm{d}=20 \mathrm{~mm}$

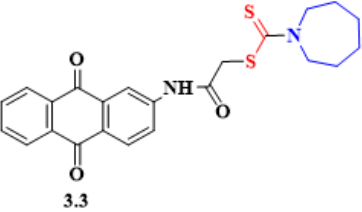

M. luteum $\mathrm{d}=18 \mathrm{~mm}$, $\mathrm{MIC}=7.8 \mu \mathrm{g} / \mathrm{ml}$ C. tenuis $\mathrm{d}=20 \mathrm{~mm}$, $\mathrm{MIC}=125 \mu \mathrm{g} / \mathrm{ml}$ A. niger $\mathrm{MIK}=62.5 \mu \mathrm{g} / \mathrm{ml}$<smiles>O=C(CSC(=S)N1CCCC1)Nc1ccc2c(c1)C(=O)c1ccccc1C2=O</smiles>

M. luteum $\mathrm{MIC}=31.2 \mu \mathrm{g} / \mathrm{ml}$

C. tenuis $\mathrm{d}=26 \mathrm{~mm}$,

$\mathrm{MIC}=500 \mu \mathrm{g} / \mathrm{ml}$

Fig. 5. Active antimicrobial compounds among dithiocarbamate derivatives of 2-chloro- $N$-acetamides 3.1-3.4

In the study of the antimicrobial action of hydrazone derivatives of type 6, it was found that in the studied concentrations by the diffusion method, they do not show any effect on gram-negative bacterium E. coli. Hydrazone derivative $\mathbf{6 . 5}$ at a concentration of $0.5 \%$ inhibited the growth of $S$. aureus $(\mathrm{d}=20 \mathrm{~mm})$ and $M$. luteum $(\mathrm{d}=21 \mathrm{~mm})$ test cultures, which exceeded the effect of vancomycin, for which the diameter of growth inhibition was 15 and $18 \mathrm{~mm}$, respectively. Compound 6.6 also showed its activity against $S$. aureus $(\mathrm{d}=14 \mathrm{~mm})$ in comparing to the action of the antibacterial reference drug. In diffusion experiments in agar, it was found that all the studied hydrazones did not show a high or moderate 
antifungal effect against $C$. tenuis and A. niger strains in comparison with nystatin ${ }^{17}$.

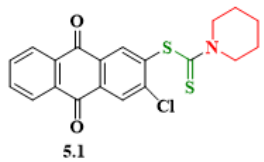

S. aureus

$\mathrm{MIC}=125 \mu \mathrm{g} / \mathrm{ml}$ M. luteum

$\mathrm{MIC}=62.5 \mu \mathrm{g} / \mathrm{ml}$ C. tenuis $\mathrm{d}=10 \mathrm{~mm}$ $\mathrm{MIC}=15.6 \mu \mathrm{g} / \mathrm{ml}$<smiles>O=C1c2ccccc2C(=O)c2cc(SC(=S)N3CCCC3)c(Cl)cc21</smiles>

M. luteum $\mathrm{d}=18 \mathrm{~mm}$ $\mathrm{MIC}=15.6 \mu \mathrm{g} / \mathrm{ml}$ C. tenuis $\mathrm{d}=21 \mathrm{~mm}$ $\mathrm{MIC}=0.9 \mu \mathrm{g} / \mathrm{ml}$ A. niger $\mathrm{d}=20 \mathrm{~mm}$ $\mathrm{MIC}=62.5 \mu \mathrm{g} / \mathrm{ml}$

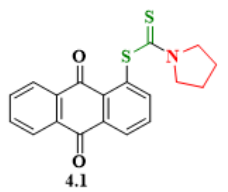

E. coli $\mathrm{d}=13 \mathrm{MM}, \mathrm{MIC}=3.9 \mu \mathrm{g} / \mathrm{ml}$ $S$. aureus $\mathrm{d}=11 \mathrm{MM}, \mathrm{MIC}=7.8 \mu \mathrm{g} / \mathrm{ml}$ $M$. luteum $\mathrm{d}=19 \mathrm{MM}, \mathrm{MIC}=7.8 \mu \mathrm{g} / \mathrm{ml}$

C. tenuis $\mathrm{d}=19 \mathrm{MM}, \mathrm{MIC}=0.9 \mu \mathrm{g} / \mathrm{ml}$ A. niger $\mathrm{d}=21 \mathrm{MM}, \mathrm{MIC}=125 \mu \mathrm{g} / \mathrm{ml}$

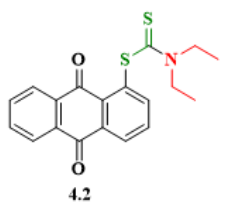

S. aureus $\mathrm{MIC}=62.5 \mu \mathrm{g} / \mathrm{ml}$ $M$. luteum $\mathrm{d}=12.0 \mathrm{~mm}, \mathrm{MIC}=15.6 \mu \mathrm{g} / \mathrm{ml}$ C. tenuis $\mathrm{d}=16.0 \mathrm{~mm}, \mathrm{MIC}=62.5 \mu \mathrm{g} / \mathrm{ml}$ A. niger $\mathrm{d}=12.0 \mathrm{~mm}$

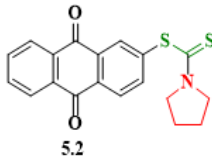

$S$. aureus $\mathrm{d}=15 \mathrm{~mm}$, $\mathrm{MIC}=15.6 \mu \mathrm{g} / \mathrm{ml}$ M. luteum $\mathrm{d}=17 \mathrm{~mm}$, $\mathrm{MIC}=7.8 \mu \mathrm{g} / \mathrm{ml}$ C. tenuis $\mathrm{d}=21 \mathrm{~mm}$, $\mathrm{MIC}=0.9 \mu \mathrm{g} / \mathrm{ml}$ A. niger $\mathrm{d}=21 \mathrm{~mm}$, $\mathrm{MIC}=31.2 \mu \mathrm{g} / \mathrm{ml}$<smiles>CCN(CC)C(=S)Sc1ccc2c(c1)C(=O)c1ccccc1C2=O</smiles>

M. luteum $\mathrm{d}=19 \mathrm{~mm}$ $\mathrm{MIC}=62.5 \mu \mathrm{g} / \mathrm{ml}$ C. tenuis $\mathrm{d}=15 \mathrm{~mm}$ A. niger $\mathrm{d}=17 \mathrm{~mm}$

Fig. 6. Active antimicrobial compounds among 9,10-dioxoanthracenyl dithiocarbamates of type 4 and 5

When establishing accurate MICs by the serial dilutions method, it was found that hydrazones $\mathbf{6 . 5}$ and $\mathbf{6 . 6}$ caused the following inhibitory effects: with $\mathrm{MIC}=250 \mu \mathrm{g} / \mathrm{ml}$ relative to $E$. coli culture, with MIC $=125 \mu \mathrm{g} / \mathrm{ml}$ with respect to strain of bacteria S. aureus, with MIC $=62.5$ and $125 \mu \mathrm{g} / \mathrm{ml}$ against $M$. luteum, and at $\mathrm{MIC}=62.5$ and $250 \mu \mathrm{g} / \mathrm{ml}$ in relation to the culture of fungus $C$. tenuis (Fig. 7).

Hydrazone 6.3 had an inhibitory effect on cultures of bacteria $M$. luteum and fungus $C$. tenuis at $\mathrm{MIC}=125 \mu \mathrm{g} / \mathrm{ml}$. Compounds 6.1, 6.2 exhibited a fungistatic effect on $C$. tenuis strain at $\mathrm{MIC}=250 \mu \mathrm{g} / \mathrm{ml}$. Derivative 6.4 showed antibacterial activity against $E$. coli strain at

17 Stasevych M., Zvarych V., Lunin V., Kopak N., Komarovska-Porokhnyavets O., Deniz N.G., Sayil C., Ozyurek M., Guclu K., Vovk M., Novikov V. Synthesis, investigation of antimicrobial and antioxidant activity of anthraquinonylhydrazones. Monatshefte für Chemie. 2018. Vol. 149. P. 1111-1119. 
MIC $=500 \mu \mathrm{g} / \mathrm{ml}$, and antifungal activity against $C$. tenuis at $\mathrm{MIC}=62.5 \mu \mathrm{g} / \mathrm{ml}$ (Fig. 7).

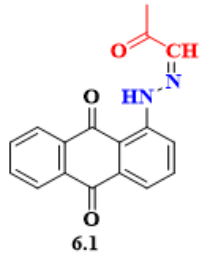

C. tenuis $\mathrm{MIC}=250 \mu \mathrm{g} / \mathrm{ml}$

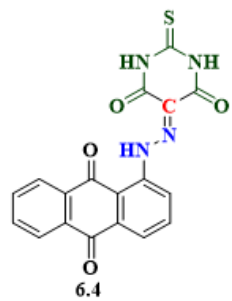

E. coli $\mathrm{MIC}=500 \mu \mathrm{g} / \mathrm{ml}$

C. tenuis $\mathrm{MIC}=62.5 \mu \mathrm{g} / \mathrm{ml}$

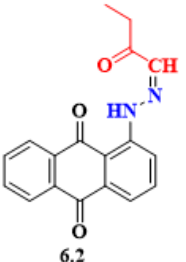

C. tenuis $\mathrm{MIC}=250 \mu \mathrm{g} / \mathrm{ml}$

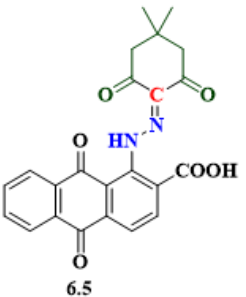

E. coli $\mathrm{MIC}=250 \mu \mathrm{g} / \mathrm{ml}$

S. aureus $\mathrm{MIC}=125 \mu \mathrm{g} / \mathrm{ml}$

$M$ luteum $\mathrm{MIC}=62.5 \mu \mathrm{g} / \mathrm{ml}$

C. tenuis $\mathrm{MIC}=62.5 \mu \mathrm{g} / \mathrm{ml}$<smiles>CCOC(=O)/C(=C\Nc1c(C(=O)O)ccc2c1C(=O)c1ccccc1C2=O)C(C)=O</smiles>

M. luteum $\mathrm{MIC}=125 \mu \mathrm{g} / \mathrm{ml}$

C. tenuis $\mathrm{MIC}=125 \mu \mathrm{g} / \mathrm{ml}$<smiles>O=C1NC(=O)C(=CNc2c(C(=O)O)ccc3c2C(=O)c2ccccc2C3=O)C(=O)NC1=O</smiles>

E. coli $\mathrm{MIC}=250 \mu \mathrm{g} / \mathrm{ml}$ S. aureus $\mathrm{MIC}=125 \mu \mathrm{g} / \mathrm{ml}$ M. luteum $\mathrm{MIC}=125 \mu \mathrm{g} / \mathrm{ml}$ C. tenuis $\mathrm{MIC}=250 \mu \mathrm{g} / \mathrm{ml}$

Fig. 7. Active antimicrobial compounds among hydrazone derivatives 6.1-6.6

\section{Antimicrobial action of heterocyclic derivatives of 9,10-anthraquinone}

Among the pyrrole derivatives of 9,10 -anthracenedione type $7^{18}$ by in vitro testing against a number of the above test cultures of bacteria and fungi, one of the most active derivative was identified with the diameter of the zone of inhibition of $E$. coli strain $(\mathrm{d}=23 \mathrm{~mm})$ in the study concentration of $0.5 \%$ and with $\mathrm{MIC}=3.9 \mu \mathrm{g} / \mathrm{ml}$. Also, for this compound, the effect on the strain of test culture of bacterium M. luteum was revealed and a MIC value was established (Fig. 8).

18 Zvarych V.I., Stasevych M.V., Lunin V.V., Vovk M.V., Novikov V.P. Synthesis of (1H-pyrrol-1-yl)anthracene-9,10-diones. Chemistry of Heterocyclic Compounds. 2016. Vol. 52. P. 421-423. 
<smiles>O=C1c2ccccc2C(=O)c2c1ccc(C(=O)O)c2-n1cccc1</smiles>

\section{E. coli $\mathrm{d}=23 \mathrm{~mm}$,}

$\mathrm{MIC}=3.9 \mu \mathrm{g} / \mathrm{ml}$

M. luteum $\mathrm{d}=12 \mathrm{~mm}$,

$\mathrm{MIC}=31.2 \mu \mathrm{g} / \mathrm{ml}$

Fig. 8. Active compound with antibacterial action among pyrrolylantracenediones type 7

The study of the antimicrobial properties of antra[1,2d] $[1,2,3]$ triazine-4,7,12(3H)-triones 8.1-8.17 ${ }^{18}$ was carried out in relation to the following test cultures strains of $S$. aureus ATCC 25923, S. aureus ATCC 29213, S. epidermidis ATCC 12228, P. aeruginosa ATCC 27853 and E. coli ATCC 25922, and fungi C. albicans ATCC 10231, C. albicans SC5314, C. krusei DSM 6128 and C. glabrata DSM 11226. Ampicillin, gentamicin, fusidic acid, linezolid, daptomycin, oxacillin and levofloxacin were taken as reference drugs (Table 1).

Table 1

Antimicrobial activity of reference drugs

\begin{tabular}{|c|c|c|c|c|c|c|c|c|c|}
\hline \multirow[b]{2}{*}{$\begin{array}{c}\text { Reference } \\
\text { drug }\end{array}$} & \multicolumn{9}{|c|}{ Microorganism, MIC, $\mu \mathrm{g} / \mathrm{ml}$} \\
\hline & 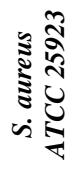 & 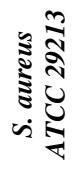 & 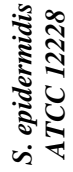 & 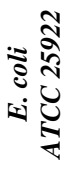 & 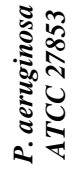 & 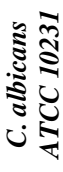 & 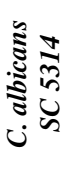 & 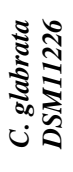 & 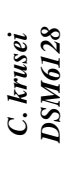 \\
\hline Ampicillin & 0.25 & 8.0 & 16 & $>32.0$ & $>32.0$ & $\mathrm{n} / \mathrm{d}$ & $\mathrm{n} / \mathrm{d}$ & $\mathrm{n} / \mathrm{d}$ & $\mathrm{n} / \mathrm{d}$ \\
\hline Gentamicin & 0.125 & 0.5 & 0.5 & 2.0 & 2.0 & $\mathrm{n} / \mathrm{d}$ & $\mathrm{n} / \mathrm{d}$ & $\mathrm{n} / \mathrm{d}$ & $\mathrm{n} / \mathrm{d}$ \\
\hline Fusidic acid & 0.5 & 0.25 & 0.125 & $>32.0$ & $>32.0$ & $\mathrm{n} / \mathrm{d}$ & $\mathrm{n} / \mathrm{d}$ & $\mathrm{n} / \mathrm{d}$ & $\mathrm{n} / \mathrm{d}$ \\
\hline Linezolid & 2.0 & 1.0 & 1.0 & $>32.0$ & $>32.0$ & $\mathrm{n} / \mathrm{d}$ & $\mathrm{n} / \mathrm{d}$ & $\mathrm{n} / \mathrm{d}$ & $\mathrm{n} / \mathrm{d}$ \\
\hline Daptomycin & 1.0 & 1.0 & 2.0 & $>32.0$ & $>32.0$ & $\mathrm{n} / \mathrm{d}$ & $\mathrm{n} / \mathrm{d}$ & $\mathrm{n} / \mathrm{d}$ & $\mathrm{n} / \mathrm{d}$ \\
\hline Oxacillin & 0.25 & 0.125 & 0.125 & $>32.0$ & $>32.0$ & $\mathrm{n} / \mathrm{d}$ & $\mathrm{n} / \mathrm{d}$ & $\mathrm{n} / \mathrm{d}$ & $\mathrm{n} / \mathrm{d}$ \\
\hline Levofloxacin & 0.125 & 0.25 & 0.125 & $>32.0$ & $>32.0$ & $\mathrm{n} / \mathrm{d}$ & $\mathrm{n} / \mathrm{d}$ & $\mathrm{n} / \mathrm{d}$ & $\mathrm{n} / \mathrm{d}$ \\
\hline
\end{tabular}

$n / d$ - the effect is not determined.

18 Zvarych V., Stasevych M., Novikov V., Rusanov E., Vovk M., Szweda P., Grecka K., Milewski S. Anthra[1,2-d][1,2,3]triazine-4,7,12(3H)-triones as a new class of antistaphylococcal agents: synthesis and biological evaluation. Molecules. 2019. Vol. 24. P. 4581. 
Furthermore, 8 strains of methicillin-sensitive S. aureus (MSSA) and 4 clinical isolates of methicillin-resistant $S$. aureus (MRSA) were used for testing (Table 2).

Table 2

S. aureus MSSA and MRSA strains used for the investigation

\begin{tabular}{|c|c|c|c|c|}
\hline No. & $\begin{array}{c}\text { Code of } \\
\text { strain }\end{array}$ & Material & $\begin{array}{l}\text { Ward of } \\
\text { hospital }\end{array}$ & $\begin{array}{c}\text { Antibiogram - } \\
\text { Susceptibility Profile * }\end{array}$ \\
\hline 1 & 4471313 & Nasal swab & $\begin{array}{l}\text { Intensive } \\
\text { care }\end{array}$ & $\begin{array}{l}\text { Pen. }- \text { R, Met. }- \text { S, } \\
\text { Clin. }- \text { S, Ery. }- \text { S }\end{array}$ \\
\hline 2 & 4475564 & Nasal swab & Internal & $\begin{array}{l}\text { Pen. }- \text { R, Met. }- \text { S, } \\
\text { Clin. - R, Ery. - R }\end{array}$ \\
\hline 3 & 4476206 & Sputum & Internal & $\begin{array}{l}\text { Pen. - R, Met. - S, } \\
\text { Clin. - R, Ery. - R }\end{array}$ \\
\hline 4 & 4475131 & Pus & Internal & $\begin{array}{l}\text { Pen. }- \text { R, Met. }-\mathrm{S} \text {, } \\
\text { Clin. - R, Ery. - R }\end{array}$ \\
\hline 5 & 4466686 & Sputum & Surgical & $\begin{array}{l}\text { Pen. }- \text { R, Met. }-\mathrm{S} \text {, } \\
\text { Clin. }- \text { R, Ery. }-\mathrm{R}\end{array}$ \\
\hline 6 & 4466380 & Wound & Surgical & $\begin{array}{c}\text { Pen. }- \text { R, Met. }- \text { S, } \\
\text { Clin. }- \text { S, Ery. }- \text { S }\end{array}$ \\
\hline 7 & 4466896 & Nasal swab & Internal & $\begin{array}{c}\text { Pen. }- \text { R, Met. }- \text { S, } \\
\text { Clin. }- \text { S, Ery. }- \text { S }\end{array}$ \\
\hline 8 & 4468792 & $\begin{array}{c}\text { Pharyngeal } \\
\text { swab }\end{array}$ & Pediatrics & $\begin{array}{l}\text { Pen. }- \text { R, Met. }- \text { S, } \\
\text { Clin. }- \text { S, Ery. }- \text { S }\end{array}$ \\
\hline 9-MRSA & 9572250 & Wound & Internal & $\begin{array}{l}\text { Pen. }- \text { R, Met. - R, } \\
\text { Clin. - R, Ery. - R }\end{array}$ \\
\hline 10-MRSA & 8007171 & Wound & Laryngology & $\begin{array}{l}\text { Pen. - R, Met. - R, } \\
\text { Clin. - R, Ery. - R }\end{array}$ \\
\hline 11-MRSA & $\begin{array}{c}4530022 \\
3\end{array}$ & Blood & Pediatrics & $\begin{array}{l}\text { Pen }- \text { R, Met }- \text { R, } \\
\text { Clin }- \text { R, Ery }- \text { R }\end{array}$ \\
\hline 12-MRSA & 9935169 & Wound & Dispensary & $\begin{array}{l}\text { Pen. - R, Met. - R, } \\
\text { Clin.- R, Ery.- R }\end{array}$ \\
\hline
\end{tabular}

Identification of bacterial isolates and antibiograms were performed by Laboratory of Clinical Microbiology, University Centre for Laboratory Diagnostics, Medical University of Gda'nsk Clinical Centre with Vitek2 Biomerieux system; Pen-Penicillin, Met-Methicillin, Clin-Clindamycin, Ery-Erythromycin, $R$-resistant, $S$-sensitive.

As a result of antimicrobial screening, it was found that compounds 8.1-8.17 (Fig. 9, 10) are noted for selective antibacterial activity against test cultures S. aureus ATCC 25923, S. aureus ATCC 29213, S. epidermidis ATCC 12228. 


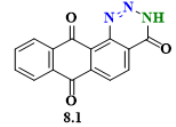

S. aureus ATCC $259234 \mu \mathrm{g} / \mathrm{ml}$ S. aumeus ATCC $292134 \mu \mathrm{gg} / \mathrm{ml}$ S. epidermidis ATCC $122288 \mathrm{\mu g} / \mathrm{ml}$<smiles>O=C1c2ccccc2C(=O)c2c1ccc1c(=O)n(C3CCCCC3)nnc21</smiles>

S. aureus ATCC $259234 \mathrm{ug} / \mathrm{ml}$ S. anoreus ATCC $292138 \mu \mathrm{g} / \mathrm{ml}$ S. avoreus ATCC $292134 \mathrm{\mu g} / \mathrm{ml}$ S. epidermidis ATCC $122288 \mathrm{\mu g} / \mathrm{ml}$ S. epidermidis ATCC $122282 \mu \mathrm{g} / \mathrm{ml}$<smiles></smiles>
8.7

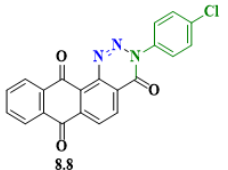

S. aureus ATCC $259231 \mathrm{\mu g} / \mathrm{ml}$ $\begin{array}{ll}\text { S. anoreus ATCC } 292132 \mathrm{\mu g} / \mathrm{ml} & \text { S. aumeus ATCC } 259232 \mathrm{\mu g} / \mathrm{ml} \\ \text { S. aumeus ATCC } 2921316 \mu \mathrm{gg} / \mathrm{m}\end{array}$ S. aureus ATCC $259232 \mu \mathrm{\mu g} / \mathrm{ml}$
S. aureus ATCC $2921316 \mu \mathrm{\mu g} / \mathrm{ml}$ S. epidermidis ATCC $122282 \mu \mathrm{g} / \mathrm{ml}$

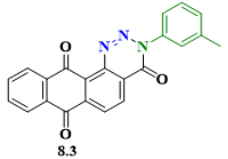

S. aureus ATCC $25923 \quad 0.5 \mu \mathrm{g} / \mathrm{ml}$ S. curreus ATCC $292130.5 \mathrm{\mu g} / \mathrm{ml}$ S. epidermidis ATCC $122280.5 \mu \mathrm{g} / \mathrm{ml}$<smiles></smiles>

S. aroreus ATCC $259234 \mathrm{\mu g} / \mathrm{ml}$ S. curreus ATCC $292138 \mu \mathrm{g} / \mathrm{ml}$ S. epidermidis ATCC $122288 \mathrm{\mu g} / \mathrm{ml}$<smiles>COc1ccccc1-n1[Y9]nc2c3c(ccc2c1=O)C(=O)c1ccccc1C3=O</smiles>

S. aureus ATCC $259232 \mathrm{\mu g} / \mathrm{ml}$ S. audreus ATCC $292132 \mathrm{\mu g} / \mathrm{ml}$ S. epidermidis ATCC $122282 \mu \mathrm{g} / \mathrm{ml}$

Fig. 9. Active compounds with antibacterial action among derivatives 8.1-8.9<smiles></smiles>

S. aureus ATCC $259238 \mathrm{ug} / \mathrm{ml}$ S. azoreus ATCC $292134 \mu \mathrm{g} / \mathrm{ml}$ S. epidermidis ATCC $122288 \mathrm{\mu g} / \mathrm{ml}$ S. awreus ATCC $292130.25 \mathrm{ug} / \mathrm{ml}$<smiles>O=C1c2ccccc2C(=O)c2c1nnn2C1CCCCC1</smiles>

8.13

S. anceus ATCC $259230.25 \mu \mathrm{g} / \mathrm{ml}$ S. anreus ATCC $292130.5 \mu \mathrm{g} / \mathrm{ml}$ S. epidermidis ATCC 122280.25 $\mu \mathrm{g} / \mathrm{m}$ S. epidermidis ATCC $122280.125 \mu \mathrm{g} / \mathrm{ml}$

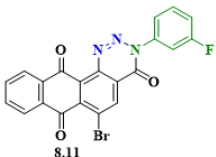

auretus ATCC $259230.25 \mathrm{\mu g} / \mathrm{m}$

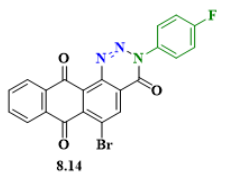

S. aroeus ATCC $259234 \mathrm{\mu g} / \mathrm{ml}$ S. aureus ATCC $292138 \mathrm{\mu g} / \mathrm{m}$

S. epidermidis ATCC $122288 \mu \mathrm{g} / \mathrm{ml}$

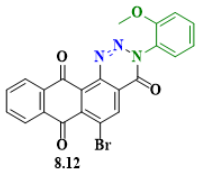

S. anreus ATCC $259230.25 \mathrm{ug} / \mathrm{ml}$

S. aureus ATCC $29213 \quad 0.25 \mathrm{ug} / \mathrm{ml}$

S. epidermidis ATCC $122280.25 \mu \mathrm{g} / \mathrm{ml}$

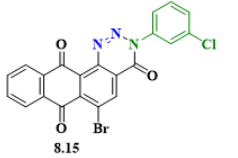

S. azoreus ATCC $259230.25 \mathrm{ug} / \mathrm{ml}$

S. aureus ATCC $292130.5 \mathrm{\mu g} / \mathrm{ml}$

S. epidermidis ATCC $122280.125 \mu \mathrm{g} / \mathrm{ml}$

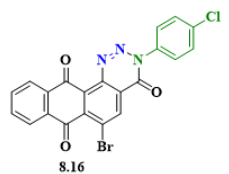

S. aureus ATCC $25923 \quad 0.5 \mu \mathrm{g} / \mathrm{ml}$

S. atoreus ATCC $292131 \mathrm{\mu g} / \mathrm{ml}$

S. epidermidis ATCC $12228 \quad 0.125 \mu \mathrm{g} / \mathrm{ml}$

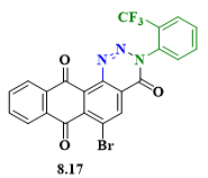

S. aureus ATCC $259231 \mathrm{\mu g} / \mathrm{ml}$

S. aureus ATCC $292132 \mathrm{\mu g} / \mathrm{ml}$

S. epidermidis ATCC $122282 \mu \mathrm{g} / \mathrm{ml}$

Fig. 10. Active compounds with antibacterial action among derivatives 8.10-8.17 
At a concentration of $1 \mu \mathrm{g} / \mathrm{ml}$ or less, eight triazinones showed inhibitory effects on S. aureus ATCC 25923, six compounds on S. aureus ATCC 29213, and seven derivatives on S. epidermidis. This antibacterial activity was within the limits of the reference drugs. At the next stage (Table 3), eight triazinones were selected to determine the level of their antibacterial action against clinical isolates of S. aureus (MSSA and MRSA).

Table 3

Antibacterial activity of eight selected anthratriazinones relative to clinical isolates of $S$. aureus (MSSA and MRSA)

\begin{tabular}{|c|c|c|c|c|c|c|c|c|c|c|c|c|}
\hline \multirow{2}{*}{$\begin{array}{l}\bar{\Xi} \\
\text { 言 }\end{array}$} & \multicolumn{12}{|c|}{ Clinical isolates S. aureus / MIC, $\mu \mathrm{g} / \mathrm{ml}$} \\
\hline & 1 & 2 & 3 & 4 & 5 & 6 & 7 & 8 & MRSA1 & MRSA2 & MRSA3 & MRSA4 \\
\hline 8.2 & 4.0 & 8.0 & 4.0 & 8.0 & 8.0 & 8.0 & 8.0 & 8.0 & 8.0 & 2.0 & 8.0 & 8.0 \\
\hline 8.3 & 1.0 & 1.0 & 0.5 & 0.25 & 0.25 & 1.0 & 0.5 & 0.5 & 1.0 & 1.0 & 0.5 & 0.5 \\
\hline 8.5 & 2.0 & 2.0 & 1.0 & 1.0 & 1.0 & 4.0 & 1.0 & 2.0 & 4.0 & 2.0 & 1.0 & 2.0 \\
\hline 8.11 & 0.25 & 0.25 & 0.25 & 0.25 & 0.25 & 0.5 & 0.25 & 0.125 & 0.25 & 0.25 & 0.25 & 0.25 \\
\hline 8.12 & 0.5 & 0.5 & 0.5 & 0.5 & 0.5 & 0.5 & 0.5 & 0.5 & 0.5 & 0.5 & 0.25 & 0.5 \\
\hline 8.13 & 0.25 & 0.5 & 0.25 & 0.25 & 0.5 & 0.25 & 0.25 & 0.25 & 0.5 & 0.125 & 0.25 & 0.25 \\
\hline 8.15 & 0.25 & 0.5 & 0.25 & 0.5 & 1.0 & 0.5 & 0.25 & 0.5 & 0.5 & 1.0 & 0.25 & 0.5 \\
\hline 8.16 & 0.5 & 0.5 & 0.5 & 1.0 & 1.0 & 0.5 & 1.0 & 0.5 & 1.0 & 1.0 & 1.0 & 2.0 \\
\hline
\end{tabular}

As can be seen from the data (Table 3), the selected triazinones also exhibited high activity against clinical isolates of $S$. aureus. It is clinically important that the difference in susceptibility to staphylococcus strains MSSA and MRSA did not differ. Four anthratriazinones 8.11-8.13, 8.15 were selected as the most promising antistaphylococcal action for further research.

Selected compounds 8.11-8.13, 8.15 were investigated for the dependence of bactericidal and bacteriostatic activity on time («time kill assay»). It was found that triazinone $\mathbf{8 . 1 2}$ was characterized only by bacteriostatic action. Other derivatives 8.11, 8.13 and 8.15 showed a bactericidal effect (Fig. 11).

Triazinone 8.13 turned out to be the most effective (Fig. 11), since a decrease in the number of bacterial cell colonies was observed after treatment of their four-fold MIC for 1 hour and two-fold MIC of the compound for 3 hours. When using triazinone derivative 8.15, this effect was achieved by processing a four-fold MIC for $1 \mathrm{~h}$. Compound 8.11 showed a bactericidal result only after 6 hours of using a four-fold MIC. Thus, according to the bactericidal effect, the most active derivative was 8.13, and then compounds 8.11 and $8.15^{19}$.

${ }^{19}$ Zvarych V., Stasevych M., Novikov V., Rusanov E., Vovk M., Szweda P., Grecka K., Milewski S. Anthra[1,2-d][1,2,3]triazine-4,7,12(3H)-triones as a new class of antistaphylococcal agents: synthesis and biological evaluation. Molecules. 2019. Vol. 24. 4581. 

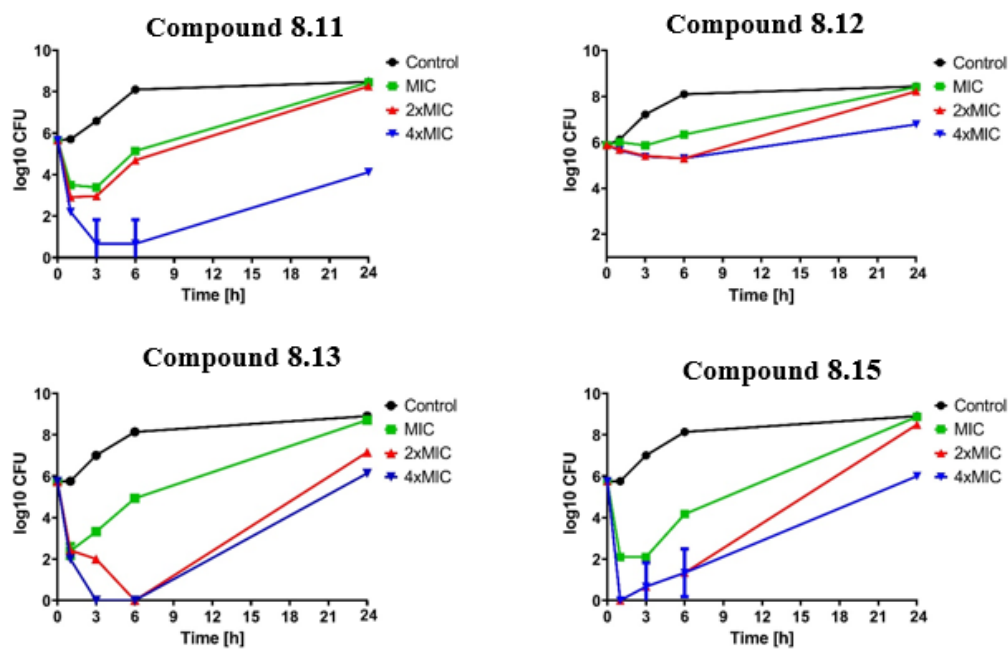

Fig. 11. Dependences of bactericidal and bacteriostatic activity on time for anthratriazinones 8.11-8.13 and 8.15

Further studies for triazinones 8.11-8.13, 8.15 were carried out at a concentration of up to $64 \mu \mathrm{g} / \mathrm{ml}(128$ or $256 \times$ MICs) on their effect on the biofilm of $S$. aureus. As a result, none of the samples under study reduces the metabolic activity of biofilm cells. However, this is not a negative result, since for many antibacterial drugs their inhibitory concentrations on the metabolism of biofilm cells can be 10-1000 times higher due to the antibiotic defense mechanism ${ }^{20}$. Therefore, the results obtained should not be considered as disadvantages of the investigated antratriazinones.

Furthermore, the effect of $1 / 2$ MIC of triazinones 8.11-8.13, 8.15 on the enzymatic activity of nineteen hydrolases of S. aureus ATCC 29213 was performed using the API ZYM semi-quantitative micromethod. The effect on the following five enzymes of bacterial cells was found: alkaline phosphatase, esterase (C4), esterase lipase (C8), acid phosphatase and naphthol-AS-BI-phosphohydrolase. For the first three enzymes, a decrease in activity was observed, while for the others it was unchanged (table 4).

${ }^{20}$ Gebreyohannes G., Nyerere A., Bii C., Sbhatu D.B. Challenges of intervention, treatment, and antibiotic resistance of biofilm-forming microorganisms. Heliyon. 2019. Vol. 5. e02192. 
Enzymatic activity of $S$. aureus ATCC 29213 strain under the influence of anthratriazinones 8.11-8.13 and 8.15

\begin{tabular}{|c|c|c|c|c|c|}
\hline \multirow[b]{2}{*}{ Compound } & \multicolumn{5}{|c|}{ Enzyme } \\
\hline & $\begin{array}{c}\text { Alkaline } \\
\text { phosphatase }\end{array}$ & $\begin{array}{l}\text { Esterase } \\
\text { (C4) }\end{array}$ & $\begin{array}{l}\text { Esterase } \\
\text { lipase } \\
\text { (C8) }\end{array}$ & $\begin{array}{c}\text { Acid } \\
\text { phosphatase }\end{array}$ & $\begin{array}{l}\text { Naphthol-AS-BI- } \\
\text { phosphohydrolase }\end{array}$ \\
\hline 8.11 & 4 & 5 & 4 & 5 & 5 \\
\hline 8.12 & 3 & 4 & 4 & 5 & 5 \\
\hline 8.13 & 3 & 3 & 4 & 5 & 5 \\
\hline 8.15 & 4 & 2 & 4 & 5 & 5 \\
\hline Control & 5 & 5 & 5 & 5 & 5 \\
\hline
\end{tabular}

\section{CONCLUSIONS}

As a result of studies of $\mathrm{N}$-acylamino anthraquinones, amino acid and dithiocarbamate derivatives of 2-chloro-N-acetamides 9,10-anthraquinone, 9,10-dioxoanthracenyl dithiocarbamates, 9,10-dioxoanthracenyl hydrazones, pyrrolyl anthracenediones and anthra[1,2- $d][1,2,3]$ triazine-4,7,12(3H)-triones expanded the arsenal and demonstrated the biological potential of synthetic derivatives of 9,10-anthraquinone with antibacterial and antifungal properties. Experimental tests in vitro have established that the most promising compounds are derivatives of 9,10-anthraquinone, functionalized with amino acid, dithiocarbamate and 1,2,3-triazinone fragments, which exhibit selective antibacterial and antifungal action against strains of test cultures of bacteria E. coli, S. aureus, M. luteum and fungi C. tenuis, A. niger. Based on the results of antimicrobial screening, a relationship between the structure and action of the tested compounds was established, which is the basis for molecular modeling of compounds with specified pharmacological properties. It was found that a wide spectrum of antimicrobial and antifungal activity is characteristic of 9,10-dioxoanthracenyldithiocarbamate containing pyrolidine residue. The prospect of using the GABA-containing derivative of 2-chloro- $N$ acetamide 9,10-anthraquinone in the form of a varnish as an effective antifungal substance against the fungus $A$. niger has been shown. It was determined that among the tested heterocyclic derivatives of 9,10-anthraquinone, antra[1,2- $d][1,2,3]$ triazine-4,7,12(3H)-trione derivatives as representatives of a new class of antistaphylococcal agents were found with selective antibacterial activity against strains $S$. aureus ATCC 25923, S. aureus ATCC 29213, S. epidermidis ATCC 12228, including methicillin-sensitive $S$. aureus (MSSA) and methicillinresistant $S$. aureus (MRSA) clinical isolates. Hence, it creates the 
prospect of the development of a synthetic modification of this class of compounds and the identification of new effective antimicrobial agents.

\section{SUMMARY}

In the aspect of studies of the biological activity of 9,10anthraquinone derivatives, much attention is focused on the search for new anticancer substances, while other types of biological action, in particular antimicrobial, are presented only by examples of individual representatives. The study of antibacterial and antifungal activity is mainly presented in the literature for individual compounds and extracts obtained from natural anthraquinone-containing plant sources. Considering the powerful biological potential of 9,10-anthraquinone derivatives in general and the focus of scientific work, most of them on studies of hydroxy derivatives of 9,10-anthraquinone of natural origin, the production of which on an industrial scale is not always economically feasible. Therefore, it is promising and relevant to search for and identify derivatives with antibacterial and antifungal properties among synthetic analogs of 9,10-anthraquinone derivatives. The generalized results of work during 2013-2021 on the study and identification of effective antibacterial and antifungal compounds among the synthesized linear and heterocyclic 9,10-anthraquinones ( $N$-acylaminoanthraquinones, amino acid and dithiocarbamate derivatives of 2-chloro- $N$-acetamide 9,10-anthraquinone, 9,10-dioxoanthracenyldithiocarbamates, 9,10-dioxoanthracenylhydrazones, pyrrolylanthracenediones and anthra[1,2- $d][1,2,3]$ triazine-4,7,12(3H)-triones) are presented. The study of antimicrobial properties was carried out against bacterial strains E. coli B-906, E. coli ATCC 25922, S. aureus 209-P, S. aureus ATCC 25923, S. aureus ATCC 29213, S. epidermidis ATCC 12228, M. luteum B-917, and fungi C. tenuis VKM Y-70, C. albicans ATCC 10231, C. albicans SC5314, C. krusei DSM 6128, C. glabrata DSM 11226, A. niger VKM F-111. The effect of the structure of the synthesized compounds on the manifestation of antibacterial and antifungal activity has been established. It was found that the introduction of an $\mathrm{N}$-acyl fragment between the anthraquinone ring and the dithiocarbamate residue reduces the antibacterial and antifungal effects of the tested compounds in comparison with derivatives in which the dithiocarbamate substituent is directly connected to the anthraquinone nucleus. Functionalization of 2-chloro- $N$-acetamide 9,10-anthraquinone with the amino acid residue, in particular with the residue of $\gamma$-aminobutyric acid, leads to the manifestation of an antifungal effect against $A$. niger 
$(\mathrm{MIC}=1.9 \mu \mathrm{g} / \mathrm{ml})$ and $C$. tenuis $(\mathrm{MIC}=7.8 \mu \mathrm{g} / \mathrm{ml})$ test cultures. It has been shown that annelation of the 1,2,3-triazine residue to the 9,10 -anthraquinone ring significantly increases the antistaphylococcal effect, with the $0.125-0.5 \mu \mathrm{g} / \mathrm{ml}$ minimum inhibitory concentration of the most active anthratriazinthriones to test cultures of $S$. aureus ATCC 25923, S. aureus ATCC 29213, S epidermidis ATCC 12228, while antifungal activity against strains of C. albicans ATCC 10231, C. albicans SC5314, C. krusei DSM 6128 and C. glabrata DSM 11226 is completely absent. For some representatives of anthratriazinetriones, an effect has been established against strains of methicillin-sensitive S. aureus (MSSA) and clinical isolates of methicillin-resistant S. aureus (MRSA).

\section{References}

1. Fouillaud M., Venkatachalam M., Girard-Valenciennes E., Caro Y., Dufossé L. Anthraquinones and derivatives from marinederived fungi: Structural Diversity and Selected Biological Activities. Marine Drugs. 2016. Vol. 14, No. 4. 64.

2. Tikhomirov A.S., Shtil A.A., Shchekotikhin A.E. Advances in the discovery of anthraquinone-based anticancer agents. Recent Patents on Anti-Cancer Drug Discovery. 2018. Vol. 13. P. 159-183.

3. Winkelmann E., Raether W. Chemotherapeutically active anthraquinones. I. Aminoanthraquinones. Arzneimittelforschung. 1979. Vol. 29. P. 1504-1509.

4. Malik E.M., Muller C.E. Anthraquinones as pharmacological tools and drugs. Medicinal Research Reviews. 2016. Vol. 3. P. 705-748.

5. Горелик М.В. Химия антрахинонов и их производных. Москва : Химия, 1983. 295 с.

6. Thomson Reuters Integrity database. URL: http:// https://integrity.clarivate.com/integrity/xmlxsl/ (accessed December 14, 2019).

7. Ворожцов Н.Н. Основы синтеза промежуточных продуктов и красителей. Москва : ГосТехХимИздат, 1955. 840 с.

8. Эфрос Л.С., Горелик М.В. Химия и технология промежуточных продуктов. Ленинград : Химия, 1979. 544 с.

9. Sharma R.K., Salunkhe M.M. Solid-liquid phase transfer catalytic reaction of 1-aminoanthraquinone with alkyl halides: A case of $\mathrm{N}$-alkylation. Indian journal of chemistry. Section B: Organic including medicinal chemistry. 1999. Vol. 38. P. 210-211. 
10. Krasnokutskaya E.A., Semenischeva N.I., Filimonov V.D., Knochel P.A new, one-step, effective protocol for the iodination of aromatic and heterocyclic compounds via aprotic diazotization of amines. Synthesis. 2007. Vol. 1. P. 81-84.

11. Malmir M., Serrano R., Silva O.M.D. Anthraquinones as potential antimicrobial agents-A review. Antimicrobial research: Novel bioknowledge and educational programs 1st Edition / edited by A M. Vilas. Spain : Formatex Research Center S.L.; 2017. 694 p.

12. Masi M., Evidente A. Fungal bioactive anthraquinones and analogues. Toxins. 2020. Vol. 12. № 11. 714.

13.Zvarych V.I., Stasevych M.V., Lunin V.V., Novikov V.P., Vovk M.V. N-Acylation of amino-9,10-anthraquinones by system of strong carboxylic acid - ammonium thiocyanate. Журнал органічної та фармацевтичної хімії. 2015. Vol. 13. C. 35-40.

14.Zvarich V.I., Stasevich M.V., Stan'ko O.V., KomarovskayaPorokhnyavets E.Z., Poroikov V.V., Rudik A.V., Lagunin A.A., Vovk M.V., Novikov V.P. Computerized prediction, synthesis, and antimicrobial activity of new amino-acid derivatives of 2-chloro- $N$ (9,10-dioxo-9,10-dihydroanthracen-1-yl)acetamide. Pharmaceutical Chemistry Journal. 2014. Vol. 48. P. 584-588.

15.Zvarych V., Stasevych M., Novikov V., Vovk M. Synthesis and study of antimicrobial activity of 2-dithiocarbamate- $N$-(9,10-dioxo-9,10dihydroanthracenyl)acetamides. Biointerface Research in Applied Chemistry. 2021. V. 11. № 1. P. 7725-7734.

16.Zvarych V., Stasevych M., Lunin V., Deniz N.G., Sayil C., Ozyurek M., Guclu K., Vovk M., Novikov V. Synthesis and investigation of antioxidant activity of the dithiocarbamates derivatives of 9,10-anthracenedione. Monatshefte für Chemie. 2016. Vol. 147. P. 2093-2101.

17. Stasevych M., Zvarych V., Lunin V., Kopak N., KomarovskaPorokhnyavets O., Deniz N.G., Sayil C., Ozyurek M., Guclu K., Vovk M., Novikov V. Synthesis, investigation of antimicrobial and antioxidant activity of anthraquinonylhydrazones. Monatshefte für Chemie. 2018. Vol. 149. P. 1111-1119.

18.Zvarych V.I., Stasevych M.V., Lunin V.V., Vovk M.V., Novikov V.P. Synthesis of (1H-pyrrol-1-yl)anthracene-9,10-diones. Chemistry of Heterocyclic Compounds. 2016. Vol. 52. P. 421-423.

19.Zvarych V., Stasevych M., Novikov V., Rusanov E., Vovk M., Szweda P., Grecka K., Milewski S. Anthra[1,2- $d][1,2,3]$ triazine4,7,12(3H)-triones as a new class of antistaphylococcal agents: synthesis and biological evaluation. Molecules. 2019. Vol. 24. 4581. 
20.Лабинская А.С. Микробиология с техникой микробиологических исследований. Москва : Медицина, 1972. С. 91-93.

21.Bongomin F., Batac C.R., Richardson M.D., Denning D.W. A review of onychomycosis due to Aspergillus species. Mycopathologia. 2018. Vol. 183. P. 485-493.

22.Kim D.M., Suh M.K., Ha G.Y., Sohng S.H. Fingernail onychomycosis due to Aspergillus niger. Annals of dermatology. 2012. Vol. 24. P. 459-463.

23. Stasevych M., Zvarych V., Novikov V. Study of the antifungal action of the lacquer based on the GABA derivative of 2-chloro- $N-(9,10-$ dioxo-9,10-dihydroanthracen-1-yl)acetamide. Biointerface Research in Applied Chemistry. 2021. Vol. 11. № 2. P. 8818-8824.

24. Yadav K. A review article on anti-fungal nail lacquer using treatment of onychomycosis. International Journal of Scientific and Research Publications. 2019. Vol. 9. № 4. P. 352-357.

25.S-(9,10-Діоксо-9,10-дигідроантрацен-1-іл)піролідин-1карбодитіоат, що має протипухлинну активність стосовно раку молочної залози людини та антимікробну дію: пат. 120193 Україна. № а201706996; заявл. 27.11.2017; опубл. 25.10.2019, Бюл. № 20. 6 с.

26. Gebreyohannes G., Nyerere A., Bii C., Sbhatu D.B. Challenges of intervention, treatment, and antibiotic resistance of biofilm-forming microorganisms. Heliyon. 2019. Vol. 5. e02192.

\section{Information about the authors: Stasevych Maryna Volodymyrivna,}

Doctor of Chemical Sciences, Associate Professor, Associate Professor at the Department of Technology of Biologically Active Substances, Pharmacy and Biotechnology

Lviv Polytechnic National University 12, Bandera str., Lviv, 79013, Ukraine

Zvarych Viktor Ihorovych, Candidate of Chemical Sciences, Senior Researcher at the Department of Technology of Biologically Active Substances, Pharmacy and Biotechnology Lviv Polytechnic National University 12, Bandera str., Lviv, 79013, Ukraine 